\section{Muskelhypotonie beim Säugling, plötzliche}

\section{Helga Peter}

Marburg, Deutschland

\section{Definition}

Plötzlich und phasenweise auftretende Hypotonie der Skelettmuskulatur beim Säugling kann ein klinischer Hinweis auf das Vorliegen von zentralen Apnoen bzw. zentral ausgelöster alveolärer Hypoventilation sein.

Siehe auch

- „Zentrale Schlafapnoesyndrome“

- „Diagnostik der Schlafbezogenen Atmungsstörungen“ 